\title{
PENGARUH KOMPOSISI PENGISI SERTA TEKANAN HOT PRESS TERHADAP KEKUATAN TARIK KOMPOSIT POLIESTER BERPENGISI PARTIKEL ZINC OXIDE (ZnO)
}

\section{THE EFFECT OF FILLER LOADING AND PRESSURE OF HOT PRESS ON TENSILE STRENGTH OF ZINC OXIDE FILLED POLYESTER COMPOSITES}

\author{
Hamzah Arifin Sinambela*, Maulida \\ Departemen Teknik Kimia, Fakultas Teknik, Universitas Sumatera Utara, \\ Jalan Almamater, Medan, 20155, Indonesia \\ *Email: hamzah.a.sinambela@gmail.com
}

\begin{abstract}
Abstrak
Penelitian ini bertujuan untuk mengetahui pengaruh penambahan pengisi zinc oxide $(\mathrm{ZnO})$ dan tekanan hot press terhadap kekuatan tarik dan karakteristik Scanning Electron Microscope (SEM) komposit poliester berpengisi zinc oxide $(\mathrm{ZnO})$. Komposit disediakan dengan poliester sebagai matriks, katalis yang digunakan metil etil keton peroksida (MEKPO) dan dicampur dengan zinc oxide $(\mathrm{ZnO})$ sebagai pengisi dengan penambahan komposisi zinc oxide $(\mathrm{ZnO}) 0 \% ; 1 \% ; 3 \%$; 5\%; dan $7 \%$ (b/b) yang dicetak dengan alat hot press dengan variasi tekanan 50 psi, 75 psi, 100 psi, 125 psi dan 150 psi. Komposit yang telah dicetak kemudian dilakukan uji kekuatan tarik dan pengujian karakteristik Scanning Electron Microscope (SEM). Hasil kekuatan tarik terbaik ditemukan pada penambahan 3\% $\mathrm{ZnO}$ (b/b) pada tekanan 150 Psi dengan kekuatan tarik $54 \mathrm{MPa}$. Karakterisasi SEM menunjukkan permukaan putus yang lebih kasar yaitu pada penambahan 3\% $\mathrm{ZnO}$ pada tekanan 150 psi karena pembasahan yang baik antara matriks dan pengisi $\mathrm{ZnO}$.
\end{abstract}

Kata kunci: hot press, poliester, komposit, kekuatan tarik, zinc oxide

\begin{abstract}
The aim of this research was to determine the effects of filler loading and pressure of hot press on tensile strength of zinc oxide ( $\mathrm{ZnO}$ ) filled polyester composites. The Composites were prepared by using polyester as the matrix, methyl ethyl ketone peroxide (MEKPO) as the catalyst. The composites were filled by the zinc oxide at 0\%; 1\%; 3\%; 5\%; and 7\% were molded by hot press with pressure variation of 50 psi, 75 psi, 100 psi, 125 psi and 150 psi. Composites have been molded, then tested for the characteristics Scanning Electron Microscope (SEM) and tests of tensile strength. The best result of tensile strength, impact and flexural were found on the addition of $3 \% \mathrm{ZnO}$ at a pressure of 150 psi with a tensile strength of $54 \mathrm{MPa}$. SEM characterization showed a rougher surface is breaking up on the addition of $3 \% \mathrm{ZnO}$ at a pressure of 150 psi because had a good wetting between matrix and filler $\mathrm{ZnO}$.
\end{abstract}

Keywords: hot press, polyester, composites, tensile strength, zinc oxide

\section{Pendahuluan}

Saat ini, penggunaan polimer di dunia industri berkembang sangat pesat. Hal ini disebabkan karakteristik polimer yang ringan, murah, tahan korosi dan memiliki suhu pengolahan yang relatif lebih rendah dibandingkan dengan bahan logam atau keramik. Secara umum, polimer dicampur dengan bahan lain untuk mendapatkan karakteristik yang lebih baik, yang dikenal sebagai material komposit. Untuk meningkatkan karakteristik yang diinginkan dalam polimer seperti kekuatan, kekakuan, dan ketahanan api, perlu ditambahkan suatu pengisi.

Komposit adalah bahan yang terdiri dari campuran atau kombinasi dari dua atau lebih unsur utama yang berbeda dalam bentuk dan / atau komposisi material yang pada dasarnya tidak dapat dipisahkan. Keuntungan dari material komposit dibandingkan dengan logam adalah ketahanannya terhadap korosi atau pengaruh lingkungan dan beberapa jenis komposit lebih baik dalam hal kekuatan dan kekakuan [14]. Komposit partikel merupakan komposit yang 
menggunakan partikel sebagai penguatnya dan terdistribusikan secara merata dalam matriksnya. Bahan komposit partikel terdiri dari partikelpartikel yang diikat oleh matriks.

Resin poliester adalah resin yang paling banyak digunakan dalam berbagai aplikasi resin termoset. karena resin ini mudah didapat, harganya relatif terjangkau dan yang terpenting mudah dalam proses fabrikasi. Jenis resin poliester yang biasa digunakan sebagai matriks komposit adalah poliester yang tidak jenuh, yaitu termoset yang dapat menjalani proses curing dari fase cair menjadi fase padat ketika perlakuan yang tepat diterapkan [2].

Seng Oksida merupakan senyawa anorganik berbentuk serbuk putih, hampir tidak larut dalam air. Biasanya banyak digunakan sebagai aditif ke dalam berbagai bahan dan produk termasuk plastik, keramik, kaca, semen, karet dan pelumas. Keuntungan penggunaan $\mathrm{ZnO}$ misalnya adalah harganya murah, persediaan di alam dalam jumlah yang melimpah, struktur kimia stabil, mudah untuk mempersiapkan, dan tidak beracun [10]. Seng oksida banyak dikembangkan karena sifat-sifat uniknya seperti fotokatalitik, elektrik, optik, dan antibakteri [5].

\section{Teori}

Komposit adalah suatu material yang terdiri dari campuran atau kombinasi dua atau lebih material dimana sifat material tersebut berbeda bentuk dan komposisi kimia dari zat asalnya [11]. Umumnya, sifat komposit akan menjadi lebih baik ketika dilakukan penggabungan material [8]. Komposit juga dapat dikatakan gabungan antara bahan matrik atau pengikat yang diperkuat. Bahan material terdiri dari dua bahan penyusun, yaitu bahan utama sebagai pengikat dan bahan pendukung sebagai penguat. Bahan penguat dapat berbentuk serat, partikel, serpihan atau dapat berbentuk yang lain [9].

Dalam struktur komposit, bahan komposit partikel tersusun dari partikel-partikel disebut bahan komposit partikel (particulate composite). Partikel ini berbentuk beberapa macam seperti bulat, kubik, tetragonal atau bahkan berbentuk yang tidak beraturan secara acak, tetapi rata-rata berdimensi sama. Bahan komposit partikel pada umunya lebih lemah dibanding bahan komposit serat. Bahan komposit partikel mempunyai keunggulan, seperti ketahanan terhadap aus, tidak mudah retak dan mempunyai daya pengikat dengan matrik yang baik [15].

Bentuk (dimensi) dan struktur penyusun komposit akan mempengaruhi karakteristik komposit, begitu pula jika terjadi interaksi antara penyusun akan meningkatkan sifat dari komposit. Dibanding dengan material konvensional, bahan komposit memiliki banyak keunggulan, diantaranya memiliki kekuatan yang dapat diatur, berat yang lebih ringan, kekuatan dan ketahanan yang lebih tinggi, tahan korosi, dan tahan terhadap keausan. Pada umumnya dalam proses pembuatannya melalui pencampuran yang homogen, sehingga kita leluasa merencanakan kekuatan material komposit yang kita inginkan dengan mengatur komposisi dari material pembentuknya [9].

Komposit terdiri dari penguat (reinforcement) dan pengikat (matriks). Reinforcement adalah salah satu bagian utama dari komposit yang berfungsi sebagai penanggung beban utama pada komposit. Bahan penguat (reinforcement) biasanya kaku dan tangguh [7]. Bahan penguat yang umum digunakan adalah jenis partikel, serat serat alam, serat karbon, serat gelas dan keramik [9]. Matriks berfungsi untuk menjaga reinforcement agar tetap pada tempatnya di dalam struktur, melindungi filamen dalam struktur, membantu distribusi beban, mengendalikan sifat elektrik dari kmia komposit, serta membawa regangan interlaminer. Matriks yang paling sering digunakan adalah logam, polimer, dan keramik [6].

Pada suatu komposit terdapat suatu fasa antarmuka, dimana fasa antarmuka ini dapat menentukan sifat mekanik suatu komposit. Fasa antarmuka merupakan kawasan yang paling tinggi menerima tegangan selama dikenakan beban dari luar. Peranannya adalah memindahkan tegangan dari partikel ke partikel melalui matriks. Pada ikatan antarmuka yang kuat, pemindahan beban atau tegangan akan berlaku efektif, sebaliknya pada ikatan antarmuka yang lemah, partikel akan terurai dari matriks apabila tegangan yang diterima lebih besar daripada ikatan antarmuka. [3]

Metil etil keton peroksida (MEKPO) adalah suatu bahan kimia yang dikenal dengan sebutan katalis. Katalis ini termasuk senyawa polimer dengan bentuk cair, berwarna bening. Fungsi dari katalis adalah mempercepat proses pengerasan (curing) pada bahan matriks suatu komposit. Semakin banyak katalis yang dicampurkan pada cairan matriks akan mempercepat proses laju pengeringan, tetapi akibat mencampurkan katalis terlalu banyak adalah membuatan komposit menjadi getas. Penggunaan katalis sebaiknya diatur berdasarkan kebutuhannya [4]. 


\section{Metodologi Penelitian \\ Bahan Baku dan Peralatan}

Material yang digunakan yaitu poliester tak jenuh yang dicampur dengan metil etil keton peroksida (MEKPO) sebagai katalis yang diperoleh dari PT Justus Kimia Raya, Medan Indonesia. Seng Oksida yang digunakan berasal dari CV. Rudang Jaya.

Alat yang digunakan meliputi mesin hot press, neraca elektrik, beaker glass, batang pengaduk, cetakan.

\section{Prosedur Pembuatan Komposit}

Proses pembuatan komposit diawali dengan menimbang massa matriks poliester dan partikel $\mathrm{ZnO}$ yang di inginkan dengan perbandingan $0 \%$, $1 \%, 3 \%, 5 \%$ dan $7 \%$. Kemudian dilakukan pencampuran matriks dengan pengisi sesuai dengan perbandingan ke dalam wadah. Pada alas cetakan diberikan pelicin gliserin. Pada campuran matriks dan pengisi ditambahkan katalis MEKPO sebagai pengeras dengan perbandingan $2 \%$ dari berat matriks. Kemudian campuran dituangkan ke dalam cetakan spesimen, lalu diratakan permukaan campuran pada cetakan. Kemudian campuran yang telah dituang ke dalam cetakan di press dengan menggunakan compression molding pada tekanan 50, 75, 100, 125 dan 150 psi. Kemudian campuran yang telah di press dikeringkan pada suhu kamar, kemudian komposit dilepaskan dari cetakan. Komposit yang telah dilepaskan dari cetakan dihaluskan menggunakan alat kikir. Kemudian dilakukan karakterisasi dan pengujian pada komposit.

\section{Karakterisasi Scanning Electron Microscope (SEM)}

Tujuan dilakukan karakterisasi ini adalah untuk melihat morfologi penyebaran dengan penambahan pengisi partikel $\mathrm{ZnO}$ dalam matriks poliester.

\section{Uji Kekuatan Tarik (Tensile Strength)}

Komposit hasil spesimen dipilih dan dipotong membentuk spesimen untuk pengujian kekuatan tarik. Pengujian kekuatan tarik dilakukan dengan tensometer.

\section{Hasil dan Pembahasan \\ Analisa Scanning Electron Microscope (SEM) Komposit Berpengisi Zinc Oxide (ZnO) \\ Pada Gambar 1(a) dapat dilihat dengan penambahan $3 \%$ zinc oxide $(\mathrm{ZnO})$ pada 150 psi, dimana morfologi sampel putus komposit yang dihasilkan terlihat lebih kasar dan terlihat bahwa zinc oxide $(\mathrm{ZnO})$ yang ditambahkan cukup}

tersebar secara merata dan memenuhi ruangruang matriks.

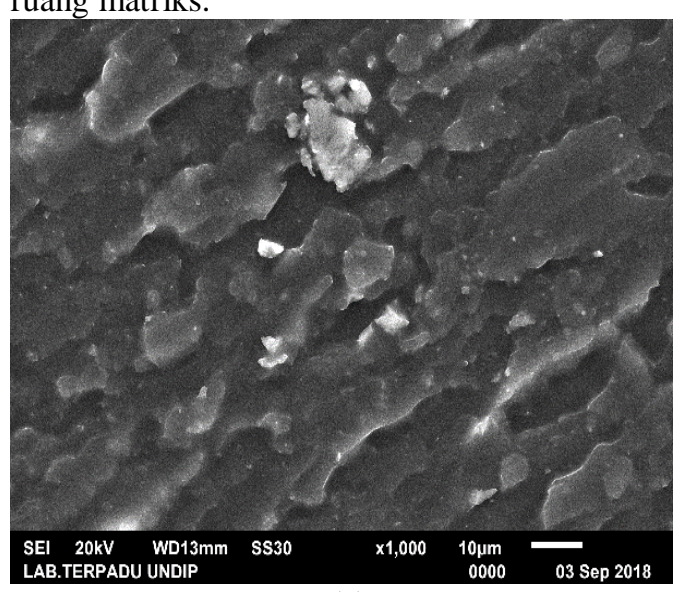

(a)

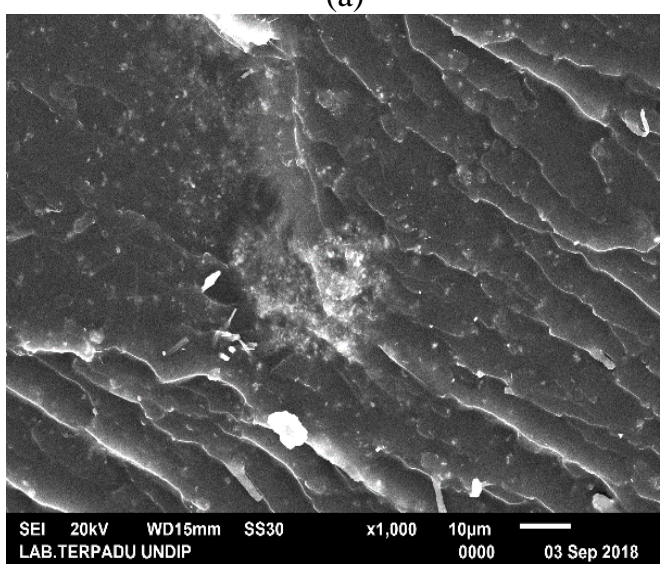

(b)

Gambar 1. Hasil Analisis Scanning Electron Microscopy (a). Penambahan 3\% Zinc Oxide (ZnO) pada 150 psi (b). Penambahan $7 \%$ Zinc Oxide ( $\mathrm{ZnO})$ pada $50 \mathrm{psi}$

Permukaan yang kasar disebabkan besarnya kekuatan yang diperlukan untuk memutuskan sampel komposit. Zinc oxide $(\mathrm{ZnO})$ mempunyai luas permukaan dan pori yang cukup besar sehingga mempunyai kemampuan yang tinggi untuk menyerap matriks. Berdasarkan mekanisme tersebut, matriks poliester yang terserap pada pori zinc oxide $(\mathrm{ZnO})$ akan semakin meningkatkan pembasahan dan juga interaksi antara matriks dan juga pengisi. Namun, masih terdapat beberapa kawasan dimana pengisi yang ditambahkan belum terbasahkan secara sempurna. Selain pengaruh zinc oxide $(\mathrm{ZnO})$, morfologi komposit yang lebih kompak ini juga dipengaruhi dengan penambahan tekanan, dimana peningkatan tekanan proses akan meningkatkan kerapatan komposit yang dihasilkan. Hal ini didukung oleh penelitian Ramaniah, et.al (2012) dimana interaksi yang baik antara pengisi dengan matriks akan 
meningkatkan kekuatan mekanik yang diperoleh [12]

Pada Gambar 1(b) komposit dengan penambahan $7 \%$ zinc oxide $(\mathrm{ZnO})$ pada tekanan 50 psi menunjukkan permukaan yang lebih halus (smooth) dibandingkan dengan Gambar 4.5 (a). Hal ini disebabkan karena semakin banyaknya zinc oxide $(\mathrm{ZnO})$ yang ditambahkan, maka tidak semua $\mathrm{ZnO}$ dapat dibasahi secara baik oleh matriks sehingga memicu potensi terbentuknya penggumpalan (aglomerasi). Selain itu tekanan yang ditambahkan juga belum dapat meningkatkan kerapatan morfologi komposit yang dihasilkan. Hal ini didukung oleh penelitian Karmakar, et.al (2007) dimana semakin banyaknya penambahan pengisi justru akan mengakibatkan pengisi mengalami penggumpalan (aglomerasi) dan juga penurunan tekanan yang ditambahkan akan mengurangi kerapatan komposit yang dihasilkan [1].

\section{Analisis Kekuatan Tarik Komposit}

Gambar 2 menunjukkan pengaruh perbandingan komposisi zinc oxide $(\mathrm{ZnO})$ dan tekanan hot press terhadap kekuatan tarik komposit:

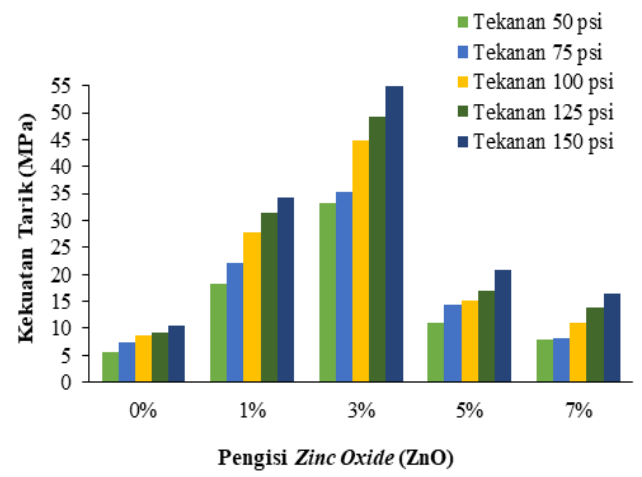

Gambar 2. Grafik Pengaruh Perbandingan Komposisi Zinc Oxide (ZnO) dan Tekanan Hot Press Terhadap Kekuatan Tarik Komposit

Pada gambar 2 dapat dilihat bahwa penambahan zinc oxide $(\mathrm{ZnO})$ dan tekanan terhadap kuat tarik komposit diperoleh nilai kuat tarik tertinggi sebesar $54 \mathrm{MPa}$ yang didapat pada penambahan zinc oxide $(\mathrm{ZnO}) 3 \%$ pada tekanan 150 psi. Nilai kuat tarik terendah diperoleh pada penambahan zinc oxide $(\mathrm{ZnO}) 7 \%$ pada tekanan 50 psi sebesar $8 \mathrm{MPa}$.

Semakin meningkatnya penambahan zinc oxide $(\mathrm{ZnO})$ yang ditambahkan maka nilai kuat tarik yang diperoleh akan semakin meningkat dibandingkan dengan komposit tanpa penambahan zinc oxide $(\mathrm{ZnO})$ sebagai pengisi. Hal ini karena zinc oxide $(\mathrm{ZnO})$ sebagai pengisi mampu mengisi ruang-ruang kosong pada matriks poliester sehingga perpindahan tegangan (stress) dari pengisi ke matriks semakin seragam dan juga zinc oxide $(\mathrm{ZnO})$ yang ditambahkan telah terdistribusi secara merata sehingga meningkatkan kuat tarik dari komposit yang dihasilkan [12]. Ketika penambahan zinc oxide $(\mathrm{ZnO})$ ditingkatkan menjadi $5 \%$ dan $7 \%$, maka nilai kuat tarik yang diperoleh akan mengalami penurunan, hal ini disebabkan ketika komposisi pengisi telah melewati suatu titik optimum, maka poliester tidak mampu lagi menyelimuti partikel zinc oxide $(\mathrm{ZnO})$ yang menyebabkan pembasahan tidak berjalan sempurna dan akan menimbulkan pemggumpalan (aglomerasi)

Peningkatan nilai kuat tarik ini juga didukung hasil analisis SEM pada nilai kuat tarik optimum (penambahan 3\% ZnO dan tekanan 150 psi) yang dapat dilihat pada gambar 1(a) dimana morfologi komposit yang dihasilkan terlihat lebih kasar dan terlihat bahwa zinc oxide $(\mathrm{ZnO})$ yang ditambahkan cukup tersebar secara merata dibeberapa kawasan dan memenuhi ruang-ruang matriks, sehingga kekuatan yang dibutuhkan untuk memutuskan sampel semakin tinggi. Zinc oxide $(\mathrm{ZnO})$ mempunyai luas permukaan dan pori yang cukup besar sehingga mempunyai kemampuan yang tinggi untuk menyerap matriks. Berdasarkan mekanisme tersebut, matriks poliester yang terserap pada pori zinc oxide $(\mathrm{ZnO})$ akan semakin meningkatkan pembasahan dan juga interaksi antara matriks dan juga pengisi.

Pada Gambar 2 juga dapat dilihat dengan bertambahnya tekanan hot press maka akan meningkatkan kerapatan komposit sehingga meningkatkan kekuatan tarik komposit yang dihasilkan. Hal ini didukung oleh penelitian Hashimoto, et.al dimana peningkatan tekanan proses akan menghasilkan suatu peningkatan densitas komposit sehingga meningkatkan sifat mekanik dari beberapa komposit [13].

\section{Kesimpulan}

Kesimpulan yang diperoleh dari penelitian ini adalah:

1. Penambahan pengisi zinc oxide $(\mathrm{ZnO})$ dan kenaikan tekanan hot press mampu meningkatkan nilai kekuatan tarik komposit. Nilai kekuatan tarik tertinggi pada penambahan komposisi zinc oxide $(\mathrm{ZnO}) 3 \%$ yaitu $54 \mathrm{MPa}$ dengan tekanan hot press 150 psi.

2. Dari hasil analisis scanning electron microscope (SEM) terhadap komposit, dapat diketahui bahwa pada penambahan $3 \%$ zinc oxide $(\mathrm{ZnO})$ tekanan hot press 150 psi terlihat pembasahan yang baik antara zinc oxide ( $\mathrm{nO})$ dengan poliester tak jenuh 
dibandingkan dengan penambahan $7 \%$ zinc oxide $(\mathrm{ZnO})$ pada tekanan 50 psi.

\section{Daftar Pustaka}

[1] A. Kamarkar, J. M. Modak, M. Chanda, S.S. Chauhan, Mechanical Properties of Wood-fiber Reinforced Polypropylene Composites: Effect of a Novel Compatibilizer with Isocyanate Functional Group, Journal Composite: Part A, 38 (2007) 227-233.

[2] B. R. George, A. Bockarie, A. Evazynajad, A. Kar, H. McBride, N. Bieak, S. Veluswamy, The Ninth Annual Conference on Recycling of Fibrous Textile and Carpet Waste, 2004, Georgia.

[3] Castiqliana, Pemanfaatan Serbuk Serat Ampas Tebu Termodifikasi sebagai Pengisi Komposit Hibrid Plastik Bekas Kemasan Gelas/Serat Ampas Tebu/Serat Kaca dengan Penambahan Bahan Penyerasi Maleat Anhidrida - g Polipropilena, Skripsi, Fakultas Teknik, Universtas Sumatera Utara, Medan, 2015.

[4] C. Oktaviana Hutagalung dan Maulida. Karakteristik Fourier Transform Infra Red dan Kekuatan Bentur Komposit Poliester Tak Jenuh Berpengisi Abu Sekam Padi Putih, Jurnal Teknik Kimia USU, 3 (2014).

[5] E. Novarini dan T. Wahyudi, Sintesis Nanopartikel Seng Oksida (Zno) Menggunakan Surfaktan sebagai Stabilisator dan Aplikasinya pada Pembuatan Tekstil Anti Bakteri, Balai Besar Tekstil, 2011.

[6] E. S. Marbun, Sintesis Bioplastik dari Pati Ubi jalar Menggunakan Penguat Logam ZnO dan Penguat Alami Selulosa. Skripsi, Fakultas Teknik, Universitas Indonesia. Depok, 2012.

[7] F. P. Aritonang, Karakteristik Komposit Berpenguat Serat Tandan Kosong Kelapa Sawit dengan Fraksi Volume 3\%, 5\% dan 7\%, Skripsi, Fakultas Sains dan Teknologi, Universitas Sanata Dharma, Yogyakarta, 2017.

[8] G. E. Nugroho, Karakteristik Komposit Berpenguat Serat Tandan Kosong Kelapa Sawit Menggunakan $\mathrm{NaoH}$ dengan Fraksi Volume 4\%, 6\% dan 8\%. Skripsi, Fakultas Sains dan Teknologi, Universitas Sanata Dharma, Yogyakarta, 2016.

[9] G. Efendi, Pengaruh Penambahan Grafit Terhadap Ketahanan Aus Komposit Abu Terbang Batubara/Phenolic, Skripsi,
Fakultas Teknik, Universitas Lampung, Lampung, 2016.

[10] J. Jiang, J. Cai, J. Pi, The Advancing of Zinc Oxide Nanoparticles for Biomedical Applications, Bioinorganic Chemistry and Applications (2018) 1-18

[11] J. Susanto, Analisis Gaya dan Pembuatan Badan Pesawat Tanpa Awak Dari Bahan Material Komposit yang Diperkuat Polyester dan Serat Wool dengan Metode Hand Lay-Up, Skripsi, Fakultas Teknik, Universitas Sumatera Utara, Medan, 2014.

[12] K. Ramaniah., A.V. Ratna Prasad, K. Hema Chandra Reddy, Thermal And Mechanical Properties of Waste Grass Broom Fiber-Reinforced Polyester Composites, Jornal of Material and Design, 40 (2012) 103-108.

[13] M. Hashimoto, H. Takadama, M. Mizuno, T. Kokubo, Enhancement of Mechanical Strength of Tio2/High-Density Polyethylene Composites for Bone Repair with Silane-Coupling Treatment, Material Research Bulletin, 41 (2006) 515-524.

[14] M. Ramesh, K. Palanikumar, K. Hemachandra Reddy, Mechanical Property Evaluation of Sisal-Jute-Glass Fiber Reinforced Polyester Composites, Composites: Part B, 48 (2013) 1-9

[15] Supiansyah, Pengaruh Variasi Volume Matriks Recycled Polypropylene (RPP) Terhadap Sifat Mekanik Komposit Serat Batang Pisang. Laporan Akhir, Jurusan Teknik Kimia, Politeknik Negeri Sriwijaya, Palembang, 2015. 